\title{
CuI Nanoparticles as a Remarkable Catalyst in the Synthesis of Benzo[b][1,5]diazepines: an Eco-friendly Approach
}

\author{
Mohammad Ali Ghasemzadeh* and Javad Safaei-Ghomi \\ Department of Chemistry, Qom Branch, Islamic Azad University, Qom, I. R. Iran \\ Department of Organic Chemistry, Faculty of Chemistry, \\ * Corresponding author: E-mail: Ghasemzadeh@qom-iau.ac.ir
}

Received: 27-06-2014

\begin{abstract}
Highly efficient CuI nanoparticles catalyzed one-pot synthesis of some benzo[b][1,5]diazepine derivatives via multicomponent condensation of aromatic diamines, Meldrum's acid and isocyanides. The present approach creates a variety of benzo[b][1,5]diazepines as pharmaceutical and biologically active heterocyclic compounds in excellent yields and short reaction times. The salient features of the copper iodide nanoparticles are: easy preparation, cost-effective, high stability, low loading and reusability of the catalyst. The prepared copper iodide nanoparticles were fully characterized by XRD, EDX, FT-IR, SEM and TEM analysis.
\end{abstract}

Keywords: Benzo[b][1,5]diazepine; nanoparticles; CuI; multi-component; heterocyclic compounds.

\section{Introduction}

Benzodiazepines are important class of nitrogencontaining heterocyclic compounds that are known to have important biological and pharmacological activities such as: analgesic, anticonvulsant, anti-depressive, antianxiety, sedative, anti-inflammatory, as well as hypnotic agents. ${ }^{1-4}$ In addition, some of the benzodiazepines have found as important drugs to treat some diseases such as cardiovascular disorders, cancer, diabetes and viral infection (HIV)..$^{5-8}$
Some of the important 1,5-benzodiazepine structures with high medicinal activity such as, olanzapine $\mathbf{1}$ and clozapine 2 (schizophrenia treatment), ${ }^{9}$ clobazam 3 (anxiolytic agents), ${ }^{10}$ and 3-carbamoyl-1,5-benzodiazepine 4 (selective CCK-B antagonists as potential anxiolyticdrugs) ${ }^{11}$ has been shown in Figure 1.

Therefore, the synthesis of 1,5-benzodiazepine derivatives due to a broad range of applications have always been the most interesting fields in the organic synthesis. The synthetic routes for the synthesis of benzodiazepines mainly are the reaction of 1,2-phenylenediamines with

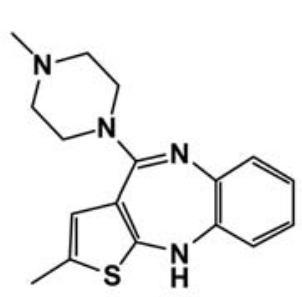

olanzapine (1)

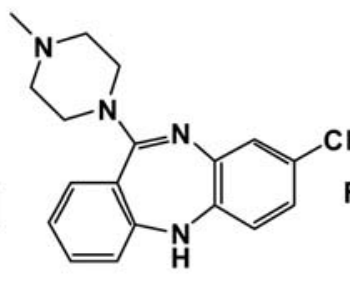

clozapine (2)<smiles>CN1C(=O)CC(=O)N(c2ccccc2)c2cc(C(F)(F)F)ccc21</smiles>

clobazam (3)<smiles>CC(C)CCN1C(=O)C(NC(=O)Oc2ccccc2)C(=O)N(c2ccccc2)c2ccc(Cl)cc21</smiles>

3-carbamoyl-1,5-benzodiazepine (4)

Figure 1. Some biologically important benzodiazepines 
various ketones, ${ }^{12}$ chalcones, ${ }^{13}$ alkynes, ${ }^{14}$ 4,6-di-o-benzyl-2,3-dideoxy-aldehydo-D-erythro-trans-hex-2-enose, ${ }^{15}$ and 3-acetyl-4-hydroxy-6-methyl-2H-pyran-2one. ${ }^{16}$ Some of these processes have some disadvantage, including toxic solvents and catalysts, long reaction times, undesirable yields and use of costly catalysts. Thus, it is necessary to develop an efficient, mild and easy procedure for the synthesis of benzodiazepines without those drawbacks.

Multi-component reactions (MCRs) are special types of synthetically useful organic reactions in which three or more various substrates react to give a final product in a one-pot procedure. ${ }^{17}$ These reactions are valuable assets in the organic synthesis and pharmaceutical chemistry due to their wide range of usage in the preparation of various structural scaffolds and discovery of new drugs. ${ }^{18}$

In the modern science, one of the growing and important fields is nanotechnology. Because of different physical and chemical properties of nano-sized catalysts compared to bulk material, they attract interests for different researcher areas. ${ }^{19}$ Since the particles are in small size, the surface area exposed to the reactant is maximized so allowing more reactions to occur at the same time, hence the process is speeded up. ${ }^{20}$

Among various nanoparticles, copper nanoparticles have extensively considered interests because of their unusual properties and potential applications in diverse fields. ${ }^{21}$ Recently, copper nanoparticles were used as an active catalyst in many reactions including carbon-heteroatom coupling, ${ }^{22,23}$ synthesis of phenols, anilines, and thiophenols, ${ }^{24}$ Synthesis of 1,4-dihydropyridines, ${ }^{25}$ alkyne-azide cycloadditions, ${ }^{26}$ the Mannich reaction, ${ }^{27}$ azaMichael reactions ${ }^{28}$ and hydroxylation of phenol. ${ }^{29}$

Recently, Shaabani et al. have reported a novel and efficient method for the synthesis of some tetrahydro-2,4dioxo-1H-benzo[b][1,5]diazepine-3-yl-2-methylpropanamide derivatives. ${ }^{30}$ This method has valuable advantages such as, mild reaction conditions, good yields and no undesirable byproducts. The times and the yields of the reported method are not satisfactory interest. So, in spite of aforementioned advantages of this method we decided to promote some aspects of this research including the reactivity of substrates. Therefore, we carried out the threecomponent reaction of 1,2-phenylenediamines, isocyanides and Meldrum's acid using metal oxide nanoparticles as efficient catalysts.
In order to achieve more efficient synthetic processes, minimize by-products, decrease the number of separate reaction steps, and also in the following of our research on the application of nanocatalysts in MCRs, ${ }^{31-37}$ we have tried to extend a clean and environment friendly approach to the synthesis of tetrahydro-2,4-dioxo-1H benzo[b][1,5]diazepine-3-yl-2-methylpropanamide derivatives via treatment of aromatic diamines, Meldrum's acid and isocyanides with excellent yields and short reaction times using CuI NPs as a catalyst (scheme 1).

\section{Results and Discussion}

The XRD pattern of CuI NPs was shown in Figure 2. All reflection peaks can be readily indexed to pure cubic phase of CuI with F-43mspace group (JCDPS No. 772391). The crystallite size diameter (D) of the CuI nanoparticles has been calculated by Debye-Scherrer equation $(\mathrm{D}=\mathrm{K} \lambda / \beta \cos \theta$ ), where $\beta$ FWHM (full-width at half-maximum or half-width) is in radian and $\theta$ is the position of the maximum of diffraction peak, $\mathrm{K}$ is the so-called shape factor, which usually takes a value of about 0.9 , and $\lambda$ is the X-ray wavelength $(1.5406 \AA$ for $\mathrm{Cu} \mathrm{K} \alpha)$. Crystallite size of $\mathrm{CuI}$ has been found to be $25 \mathrm{~nm}$.

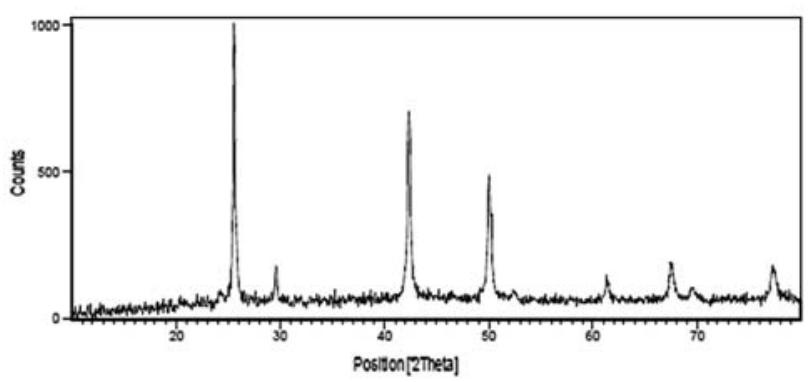

Figure 2. XRD pattern of CuI nanoparticles

The chemical purity of the samples as well as their stoichiometry was tested by EDAX studies. The EDAX spectrum given in Figure 3 shows the presence of copper and iodine as the only elementary components.

In order to study the morphology and particle size of CuI nanoparticles, SEM images of CuI NPs are shown in Figure 4 which shows copper iodide to be in nanostructure. This result shows that single phase primary particle is spherical in shape with the average diameter between 40-50 nm.

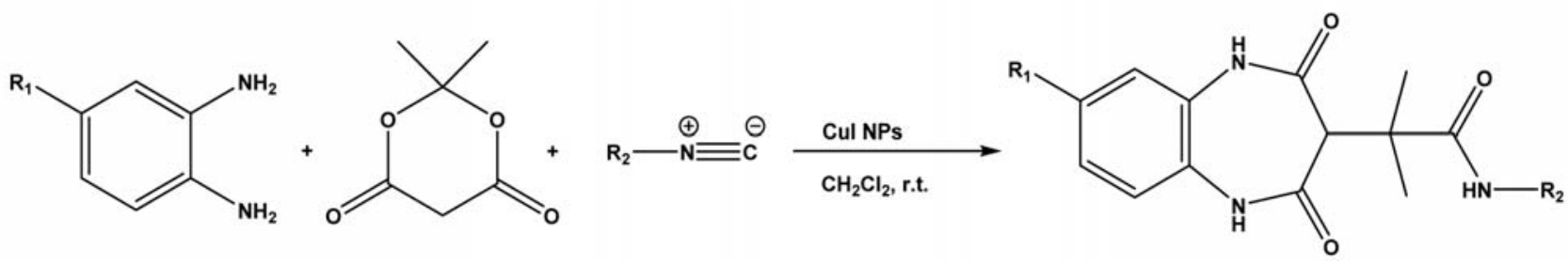

Scheme 1. Preparation of benzo[b][1,5]diazepines using CuI nanoparticles as catalyst 


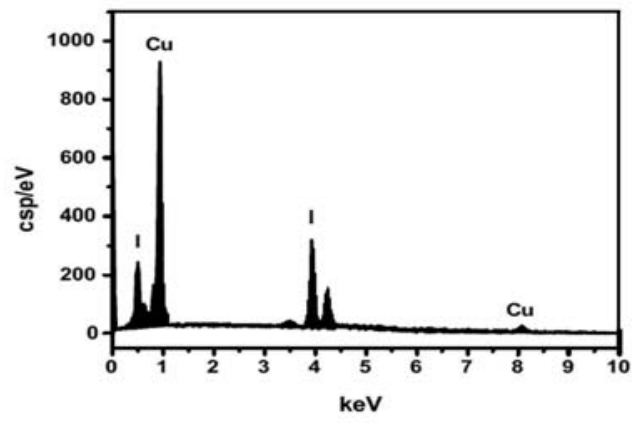

Figure 3. EDAX spectrum of CuI nanoparticles
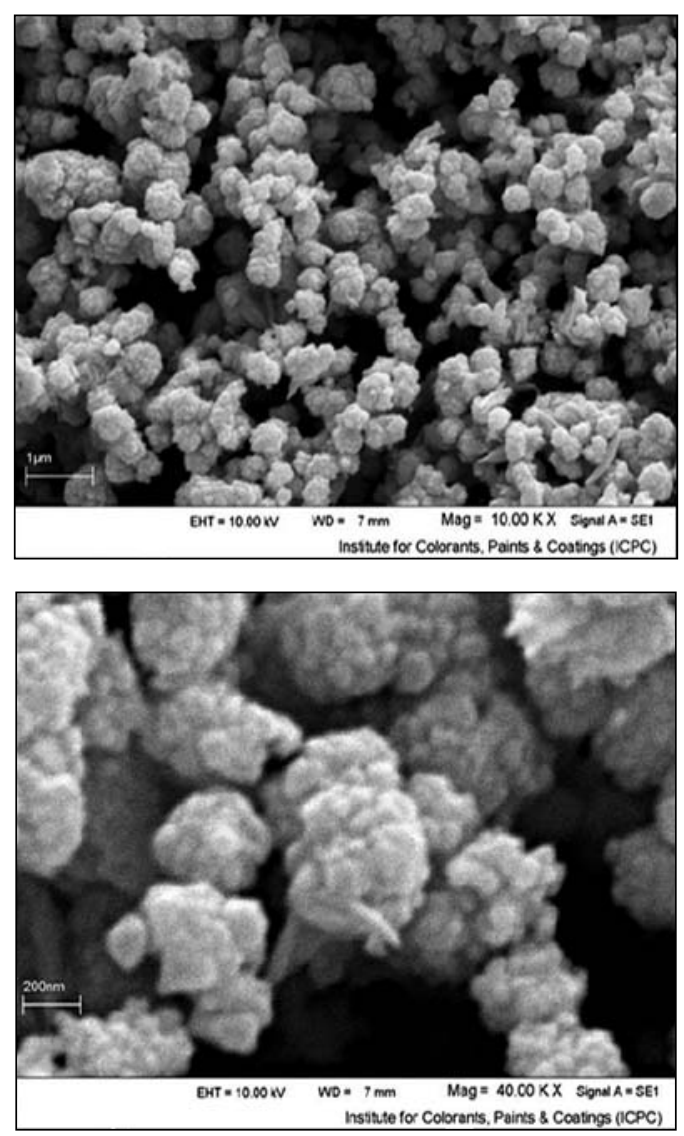

4. SEM images of CuI nanoparticles

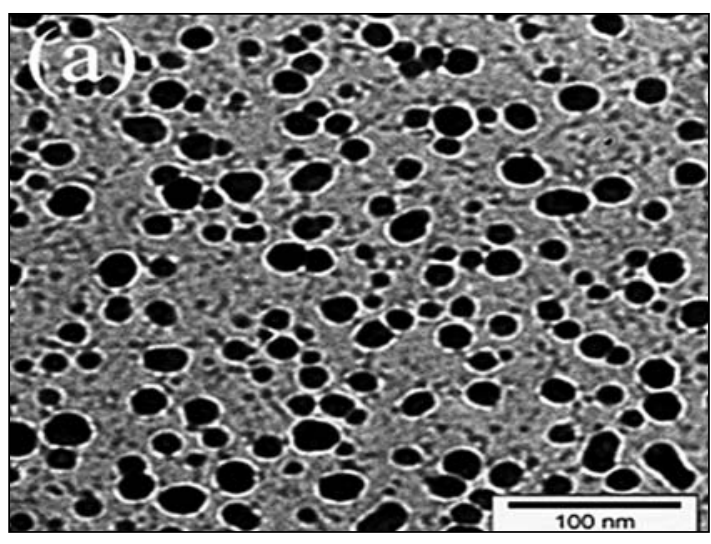

Figure 5. TEM image of CuI nanoparticles

The size and morphology of $\mathrm{CuI}$ nanoparticles were analyzed by Transmission Electron Microscopy (TEM) (Figure 5). The result shows that these nanocatalysts consist of spherical particles with the crystallite size about $25-30 \mathrm{~nm}$, which is in good agreement with XRD crystal sizes.

Figure 6 shows FT-IR spectrum of CuI nanoparticles. As shown there is no observed any specific peak related to functional groups, but the strong peak around 1583 $\mathrm{cm}^{-1}$ can be attributed to the $(\mathrm{OH})$ stretching and bending vibrations, respectively. These peaks indicate the slightly presence of physisorbed water linked to nanoparticles.

In our preliminary experiments, the model study conditions were carried out based on the reactions of $o$ phenylenediamine $(1 \mathrm{mmol})$, Meldrum's acid $(1 \mathrm{mmol})$ and tert-buthyl isocyanide $(1 \mathrm{mmol})$ in different solvents and catalysts (Scheme 2).

This model reaction was performed using the protic (Table 1, entries 1-3), aprotic (Table 1, entries 4, 5) and non polar (Table 1, entries 6,7) solvents in the presence of $10 \mathrm{~mol} \%$ of $\mathrm{CuI}$ nanoparticles.

The best result was obtained in dichloromethane (Table 1, entry 7). Next, we studied the model reaction in dichloromethane at various temperatures (Table 1, entries $7,8)$. The maximum yield was obtained at room temperature (Table 1, entry 7).

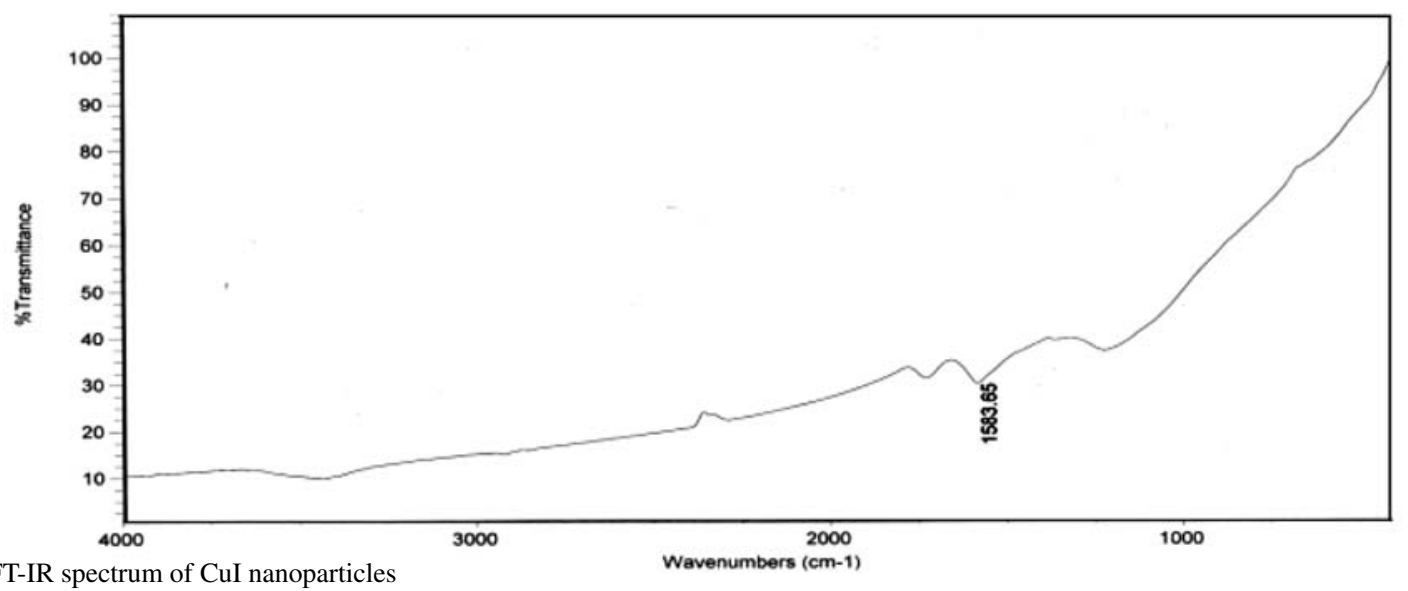

Figure 6. FT-IR spectrum of CuI nanoparticles 


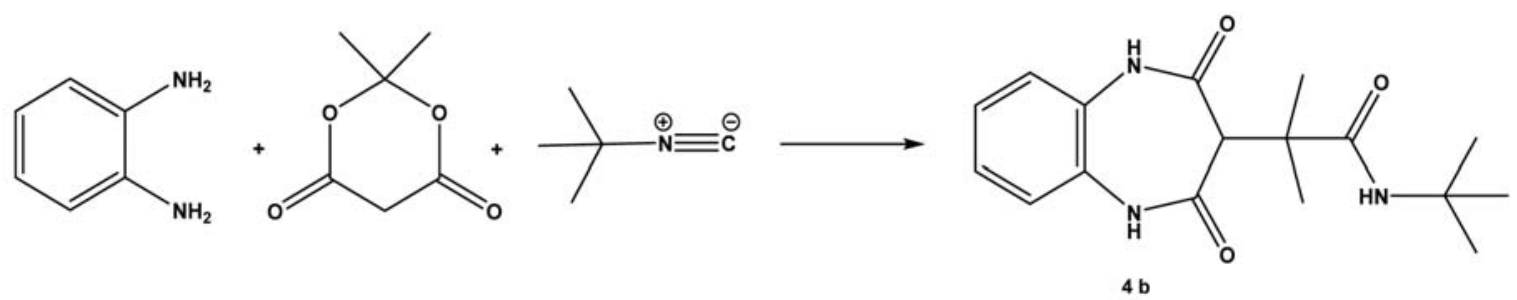

Scheme 2. The model study for the preparation of 1,5-benzodiazepin-2-one $4 \mathbf{b}$

Table 1. The model study catalyzed by CuI NPs in different solvents

\begin{tabular}{cccc}
\hline Entry & Solvent & Time $(\mathbf{h})$ & Yield $(\%)^{\mathbf{a}}$ \\
\hline 1 & $\mathrm{EtOH} /$ r.t.. & 9 & trace \\
2 & $\mathrm{H}_{2} \mathrm{O} /$ r.t & 9 & trace \\
3 & $\mathrm{CH}_{3} \mathrm{OH} /$ r.t. & 9 & trace \\
4 & $\mathrm{DMF} /$ r.t. & 6 & 45 \\
5 & $\mathrm{CH}_{3} \mathrm{CN} /$ r.t. & 6 & 50 \\
6 & $\mathrm{PhCH}_{3} /$ r.t. & 5 & 60 \\
7 & $\mathrm{CH}_{2} \mathrm{Cl}_{2} /$ r.t. & 3 & 97 \\
8 & $\mathrm{CH}_{2} \mathrm{Cl}_{2} /$ reflux & 9 & - \\
\hline
\end{tabular}

asolated yield

The model study in $\mathrm{CH}_{2} \mathrm{Cl}_{2}$ at room temperature was also established in the absence of catalyst and also in the presence of different catalysts (Table 2, entries 2-11). Although in the absence of catalyst the reaction was carried out but we obtain a moderate yield of product after $9 \mathrm{~h}$. Many homogenous and heterogeneous catalysts, such as $\mathrm{SiO}_{2}, \mathrm{CH}_{3} \mathrm{COOH}, \mathrm{MgSO}_{4}, \mathrm{NaOH}, \mathrm{MgO} \mathrm{NPs}, \mathrm{CaO} \mathrm{NPs}$, $\mathrm{CuO} \mathrm{NPs}, \mathrm{HCl}, \mathrm{H}_{2} \mathrm{SO}_{4}$, CuI NPs, etc., were used to investigate the model reaction in dichloromethane as solvent at room temperature $(15 \mathrm{~mol} \%$ of each catalyst was used separately).

The summarized results in Table 2 show that most of the Brønsted and Lewis acids could carry out the model reaction. However, we found that CuI NPs (Table 2, entry 12) give the best results in comparison with bulk $\mathrm{CuI}$ and also other catalysts in three-component reaction of $o$-phenylenediamine, Meldrum's and tert-buthyl isocyanide.

The increased catalytic activity of copper iodide nanoparticles toward others catalysts is related to the high surface area to volume ratio of nanoparticles which provides enormous driving force for diffusion.

In continue the effect of different concentrations of catalyst was evaluated using various amounts of $\mathrm{CuI}$ NPs including $1 \mathrm{~mol} \%, 3 \mathrm{~mol} \%, 5 \mathrm{~mol} \%, 8 \mathrm{~mol} \%$ and 10 mol\%. We observed that $8 \mathrm{~mol} \%$ of CuI NPs NPS afforded product with the best results and was enough to progress of the reaction (Table 2).

We investigated the scope and limitations of threecomponent (Pseudo five-component) reaction of aromatic diamines, Meldrum's acid and isocyanides under optimi-
Table 2. Synthesis of benzo[b][1,5]diazepin $\mathbf{4 b}$ using various catalysts $^{\mathrm{a}}$

\begin{tabular}{cccc}
\hline Entry & Catalyst & Time (h) & Yield (\%) $^{\mathbf{b}}$ \\
1 & none & 9 & 55 \\
2 & $\mathrm{SiO}_{2}$ & 6 & 62 \\
3 & $\mathrm{CH}_{3} \mathrm{COOH}$ & 4 & 69 \\
4 & $\mathrm{MgSO}_{4}$ & 7 & 52 \\
5 & $\mathrm{NaOH}$ & 9 & - \\
6 & $\mathrm{MgO} \mathrm{NPs}$ & 8 & 66 \\
7 & $\mathrm{CaO} \mathrm{NPs}$ & 8 & 57 \\
8 & $\mathrm{CuO} \mathrm{NPs}$ & 5 & 75 \\
9 & $\mathrm{HCl}$ & 7 & 40 \\
10 & $\mathrm{H}_{2} \mathrm{SO}_{4}$ & 6 & 45 \\
11 & $\mathrm{CuI}$ & 5 & 65 \\
12 & $\mathrm{CuI} \mathrm{NPs}$ & 3 & 97 \\
13 & $\mathrm{CuI} \mathrm{NPs} \mathrm{(1} \mathrm{mol \% )}$ & 6 & 80 \\
14 & $\mathrm{CuI} \mathrm{NPs} \mathrm{(3} \mathrm{mol \% )}$ & 4 & 85 \\
15 & $\mathrm{CuI} \mathrm{NPs} \mathrm{(5} \mathrm{mol \% )}$ & 3.2 & 88 \\
16 & $\mathrm{CuI} \mathrm{NPs} \mathrm{(8} \mathrm{mol \% )}$ & 3 & 97 \\
17 & $\mathrm{CuI} \mathrm{NPs} \mathrm{(10} \mathrm{mol \% )}$ & 3 & 97 \\
\hline
\end{tabular}

${ }^{a}$ All the reactions were carried out in dichloromethane at r.t.

${ }^{\mathrm{b}}$ Isolated yield

zed conditions. So we carried out synthesis of benzo [b][1,5]diazepine derivatives by use of various structures of $o$-phenylenediamines and isocyanides.

As shown in Table 3 both mono and disubstituted aromatic diamines were converted into the corresponding benzo[b][1,5]diazepines in excellent yields. In order to prove the generality of represented method, we next used both aliphatic and aromatic isocyanides and as a results of this we successfully synthesized a series of benzo[b][1,5]diazepines in high yields. In this case using tert-butyl isocyanide gave the best yields $(97 \%$, $98 \%$, entries 2 and 7, Table 3 ) in comparison with other isocyanides.

A plausible mechanism on the basis of our experimental results together with some literature ${ }^{30}$ for the synthesis of tetrahydro-2,4-dioxo-1H-benzo[b][1,5]diazepine-3-yl-2-methylpropanamide by CuI NPs is shown in Scheme 3. Initially we suppose that copper iodide nanoparticles coordinate to carbonyl groups of Meldrum's acid and accelerate the nucleophilic attack of 1,2-phenylenediamine. In other words interaction between CuI NPs as a Lewis acid with substrates and other intermediates promoted the rate of reaction. 
Table 3. CuI nanoparticles catalyzed one-pot synthesis of benzodiazepines ${ }^{\mathrm{a}}$

\begin{tabular}{|c|c|c|c|c|c|}
\hline Entry & $\mathbf{R}_{1}$ & $\mathbf{R}_{2}$ & Products $(4 a-4 j)$ & Time (h) & Yield $(\%)^{\mathrm{b}}$ \\
\hline 1 & $\mathrm{H}$ & cyclohexyl & & 3.2 & 94 \\
\hline 2 & $\mathrm{H}$ & tert-butyl & & 3 & 97 \\
\hline 3 & $\mathrm{H}$ & benzyl & & 3.2 & 93 \\
\hline 4 & $\mathrm{H}$ & n-pentyl & & 3.5 & 92 \\
\hline 5 & $\mathrm{H}$ & 4-methoxyphenyl & & 3.5 & 93 \\
\hline 6 & $\mathrm{CH}_{3}$ & cyclohexyl & & 3 & 95 \\
\hline 7 & $\mathrm{CH}_{3}$ & tert-butyl & & 2.5 & 98 \\
\hline 8 & $\mathrm{CH}_{3}$ & benzyl & & 3 & 95 \\
\hline 9 & $\mathrm{CH}_{3}$ & n-pentyl & & 3.2 & 94 \\
\hline 10 & $\mathrm{CH}_{3}$ & 4-methoxyphenyl & & 3.2 & 94 \\
\hline
\end{tabular}

${ }^{\text {a }}$ reaction conditions: aromatic diamines $(1 \mathrm{mmol})$, Meldrum's acid (1mmol), isocyanides (1mmol) and CuI NPs $(8 \mathrm{~mol} \%)$ in $5 \mathrm{~mL}$ $\mathrm{CH}_{2} \mathrm{Cl}_{2}$; ' Isolated Yields. 


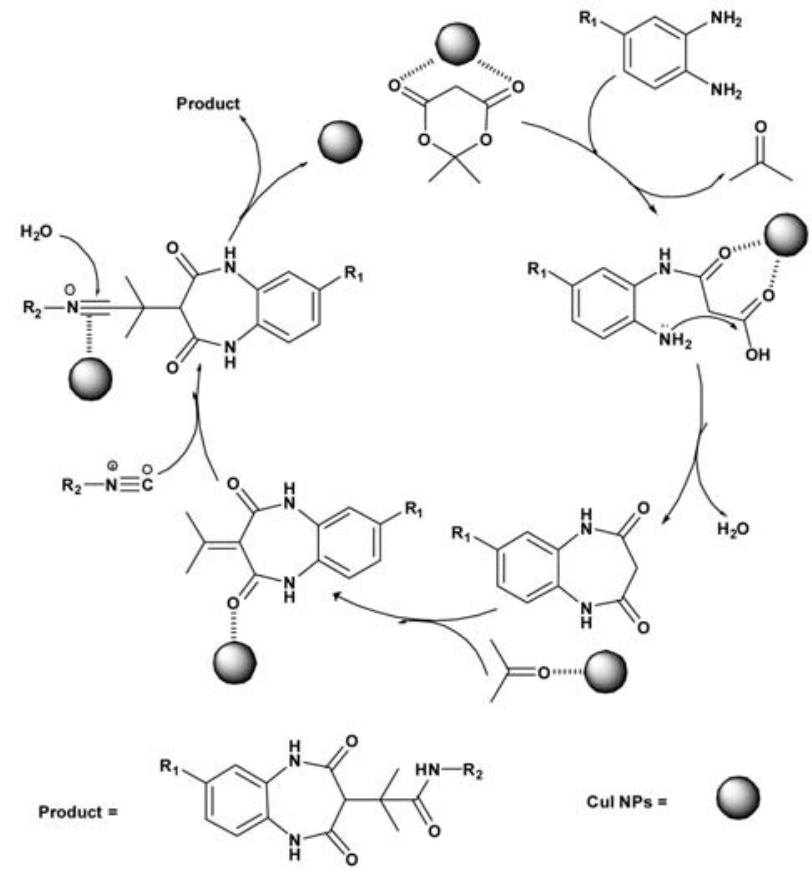

Scheme 3. Proposed reaction pathway for the synthesis of 1,5-benzodiazepin-2-ones by CuI NPs

\section{Experimental}

\section{1. General}

Chemicals were purchased from the Merck and Fluka Chemical Companies in high purity. All of the materials were of commercial reagent grade. Copper iodide nanoparticles were prepared according to the procedure reported by Kimura et al. ${ }^{38}$ IR spectra were recorded as $\mathrm{KBr}$ pellet on a Perkin-Elmer 781 spectrophotometer and an Impact 400 Nicolet FT-IR spectrophotometer. ${ }^{1} \mathrm{HNMR}$ and ${ }^{13} \mathrm{CNMR}$ spectra were recorded in $\mathrm{CDCl}_{3}$ solvent on a Bruker DRX-400 spectrometer $(400 \mathrm{MHz})$ using TMS as an internal reference. Melting points obtained with a Yanagimoto micro melting point apparatus are uncorrected. The purity determination of the substrates and reactions monitoring were accomplished by TLC on silica gel polygram SILG/UV 254 plates. The elemental analyses $(\mathrm{C}, \mathrm{H}, \mathrm{N})$ were obtained from a Carlo ERBA Model EA 1108 analyzer. PowderX-ray diffraction (XRD) was carried out on a Philips diffractometer of X'pert Company with mono chromatized $\mathrm{Ag} \mathrm{K} \alpha$ radiation $(\lambda=1.5406 \AA)$. Microscopic morphology of products was visualized by SEM (LEO 1455VP). Transmission electron microscopy (TEM) was performed with a Jeol JEM-2100UHR, operated at $200 \mathrm{kV}$. The compositional analysis was done by energy dispersive analysis of X-ray (EDAX, Kevex, Delta Class I). The mass spectra were recorded on a Joel D-30 instrument at an ionization potential of $70 \mathrm{eV}$

\section{2. Preparation of Copper iodide Nanoparticles}

The mixture of copper iodide $(0.1 \mathrm{~g}, 0.5 \mathrm{mmol})$ in 5 $\mathrm{mL}$ acetonitrile was dissolved under ultrasonic irradiation. Afterwards DMF $(10 \mathrm{~mL})$ was added to the solution and the mixture was sonicated to afford yellowish solution. The reaction mixture was stirred at $25^{\circ} \mathrm{C}$ to remove acetonitrile and then water $10 \mathrm{~mL}$ was added drop wise in to the solution under mechanical stirring. The cloudy green participate residue was centrifuged and washed several times with ethanol to afford pure $\mathrm{CuI}$ nanoparticles. The prepared nanoparticles were fully characterized by XRD, EDX, FT- IR, SEM, and TEM analysis.

\section{3. General Procedure for the Synthesis of Tetrahydro-2,4-dioxo-1H-benzo[b][1,5] diazepine-3-yl-2-methyl Propanamides $(\mathbf{4 a}-\mathbf{4 j})$.}

CuI nanoparticles $(0.016 \mathrm{~g}, 8 \mathrm{~mol} \%)$ was added to a mixture of 1,2-phenylenediamines (1mmol), Meldrum's acid (1mmol) and isocyanide (1 mmol) in $5 \mathrm{~mL}$ dichloromethane. The reaction mixture was stirred for $2.5-3.5 \mathrm{~h}$ at room temperature. Progress of the reaction was continuously monitored by TLC. After the reaction completed, the residue was dissolved in methanol and then the nanocatalyst was separated by simple filtration. The solvent was evaporated under vacuum and the solid obtained was washed several times with acetone to afford the pure benzodiazepines.

All of the products were characterized and identified with m.p., ${ }^{1} \mathrm{H}$ NMR, ${ }^{13} \mathrm{C}$ NMR and FT-IR spectroscopy techniques. Spectral data of the new products are given below.

N-pentyl-2-(2,4-dioxo-2,3,4,5-tetrahydro-1H-benzo[b][1,5]diazepin-3-yl)-2 methylpropanamide (4d).

White solid;' m.p. 286-288 ${ }^{\circ} \mathrm{C} ;{ }^{1} \mathrm{H}$ NMR (DMSO- $d_{6}$, $400 \mathrm{MHz}) \delta: 0.81-0.84$ (t, 3H, $\mathrm{CH}_{3}$ (pentyl)), 1.17-1.43 $\left(\mathrm{m}, 12 \mathrm{H}, 3 \times \mathrm{CH}_{2}\right.$ and $\left.2 \times \mathrm{CH}_{3}\right), 2.96-2.97(\mathrm{t}, 2 \mathrm{H}$, $\left.\mathrm{CH}_{2}-\mathrm{NH}\right), 3.39$ (s, 1H, CH), 7.11-7.18 (m, 4H, ArH), 7.58 (bs, $1 \mathrm{H}, \mathrm{NH}), 10.33$ (bs, $2 \mathrm{H}, 2 \mathrm{NH}) ;{ }^{13} \mathrm{C}$ NMR (DMSO- $\left.d_{6}, 100 \mathrm{MHz}\right) \delta: 14.4,22.3,28.9,29.1,29.8,43.4$, 48.1, 52.6, 112.4, 125.3, 130.4, 167.4, $177 \mathrm{~cm}^{-1}$; FT-IR $(\mathrm{KBr}) v: 3347(\mathrm{NH}), 1700(\mathrm{C}=\mathrm{O}), 1660(\mathrm{C}=\mathrm{O}), 1546$ $(\mathrm{C}=\mathrm{C}) \mathrm{cm}^{-1}$; MS (EI) (m/z): $331\left(\mathrm{M}^{+}\right)$; Anal. Calcd. for $\mathrm{C}_{18} \mathrm{H}_{25} \mathrm{~N}_{3} \mathrm{O}_{3}(\mathrm{Mr}=331.19): \mathrm{C} 65.23, \mathrm{H} 7.60, \mathrm{~N} 12$. Found C 65.09, H 7.71, N 12.69.

N-(4-methoxyphenyl)-2-(2,4-dioxo-2,3,4,5-tetrahydro1 Hbenzo[b][1,5]diazepin-3-yl)-2-methylpropanamide (4e).

White solid m.p. $306-308{ }^{\circ} \mathrm{C}{ }^{1} \mathrm{H}$ NMR (DMSO- $d_{6}$, $400 \mathrm{MHz}) \delta: 1.48-1.53\left(\mathrm{~s}, 6 \mathrm{H}, 2 \times \mathrm{CH}_{3}\right), 3.43(\mathrm{~s}, 1 \mathrm{H}$, $\mathrm{CH}), 3.69\left(\mathrm{~s}, 3 \mathrm{H}, \mathrm{OCH}_{3}\right), 6.82-6.82(\mathrm{~d}, 2 \mathrm{H}, J=8 \mathrm{~Hz}$, ArH), 7.16-7.18 (m, 4H, ArH), 7.42-7.44 (d, 2H, $J=8$ 
$\mathrm{Hz}, \mathrm{ArH}$ ), 9.53 (bs, $1 \mathrm{H}, \mathrm{NH}$ ), 10.47 (bs, $2 \mathrm{H}, 2 \mathrm{NH}$ ); ${ }^{13} \mathrm{C}$ NMR (DMSO- $\left.d_{6}, 100 \mathrm{MHz}\right) \delta: 21.8,43.1,48.5,56.1$, 122.2, 125.5, 131.4, 133.6, 135.8, 136.2, 140.1, 167.8, $177.2 \mathrm{~cm}^{-1}$; FT-IR (KBr) v: $3424(\mathrm{NH}), 1695,(\mathrm{C}=\mathrm{O}) 1654$ $(\mathrm{C}=\mathrm{O}), 1510(\mathrm{C}=\mathrm{C}), 1253(\mathrm{C}-\mathrm{O}) \mathrm{cm}^{-1}$; MS (EI) $(\mathrm{m} / \mathrm{z})$ : $367\left(\mathrm{M}^{+}\right)$; Anal. Calcd. for $\mathrm{C}_{20} \mathrm{H}_{21} \mathrm{~N}_{3} \mathrm{O}_{4}(\mathrm{Mr}=367.15)$ : $\mathrm{C}$ 65.38, H 5.67, N 11.44. Found C 65.51, H 5.59, N 11.35.

N-n-pentyl-2-methyl-2-(7-methyl-2,4-dioxo-2,3,4,5-tetrahydro1Hbenzo[b][1,5]diazepin-3-yl)propanamide (4i).

White solid; m.p. 246-248 ${ }^{\circ} \mathrm{C} ;{ }^{1} \mathrm{H}$ NMR (DMSO$\left.d_{6}, 400 \mathrm{MHz}\right) \delta: 0.92-0.95$ (t, $3 \mathrm{H}, \mathrm{CH}_{3}$ (pentyl)), $1.22-1.51\left(\mathrm{~m}, 12 \mathrm{H}, 3 \times \mathrm{CH}_{2}\right.$ and $\left.2 \times \mathrm{CH}_{3}\right), 2.22(\mathrm{~s}, 3 \mathrm{H}$, $\left.\mathrm{CH}_{3}\right), 2.93\left(\mathrm{t}, 2 \mathrm{H}, \mathrm{CH}_{2}-\mathrm{NH}\right), 3.34(\mathrm{~s}, 1 \mathrm{H}, \mathrm{CH}), 7.09-7.16$ (m, 3H, ArH), 8.11 (bs, 1H, NH), 10.43 (bs, 2H, 2NH); ${ }^{13} \mathrm{C}$ NMR (DMSO- $\left.d_{6}, 100 \mathrm{MHz}\right) \delta: 15.6,19.8,21.4,22.8$, 29.2, 29.7, 43.4, 48.2, 53.1, 112.4, 125.3, 126.7, 127.5, 128.4, 133.2, 167.2, $177.1 \mathrm{~cm}^{-1}$; FT-IR (KBr) v: 3339 $(\mathrm{NH}), 1698(\mathrm{C}=\mathrm{O}), 1659(\mathrm{C}=\mathrm{O}), 1566(\mathrm{C}=\mathrm{C}) \mathrm{cm}^{-1}$; MS (EI) (m/z): $345\left(\mathrm{M}^{+}\right)$; Anal. Calcd. for $\mathrm{C}_{19} \mathrm{H}_{27} \mathrm{~N}_{3} \mathrm{O}_{3}(\mathrm{Mr}=$ 345.21): C 66.06, H 7.88, N 12.16. Found C 66.18, H 7.79, N 12.04 .

N-(4-methoxyphenyl)-2-methyl-2-(7-methyl-2,4-dioxo2,3,4,5-tetrahydro-1Hbenzo[b][1,5]diazepin-3yl) propanamide $(\mathbf{4 j})$.

White solid;' m.p. $283-285{ }^{\circ} \mathrm{C}$; ${ }^{1} \mathrm{H}$ NMR (DMSO- $d_{6}$, $400 \mathrm{MHz}) \delta: 1.31-1.35\left(\mathrm{~s}, 6 \mathrm{H}, 2 \times \mathrm{CH}_{3}\right), 2.22(\mathrm{~s}, 3 \mathrm{H}$, $\left.\mathrm{CH}_{3}\right), 3.45$ (s, $\left.1 \mathrm{H}, \mathrm{CH}\right), 3.81\left(\mathrm{~s}, 3 \mathrm{H}, \mathrm{OCH}_{3}\right), 6.91-6.93$ (d, $2 \mathrm{H}, \mathrm{J}=7.9 \mathrm{~Hz}, \mathrm{ArH}), 7.14-7.17$ (m, 3H, ArH), 7.53-7.55 $(\mathrm{d}, 2 \mathrm{H}, \mathrm{J}=7.9 \mathrm{~Hz}, \mathrm{ArH}), 9.66$ (bs, $1 \mathrm{H}, \mathrm{NH}), 10.44$ (bs, $2 \mathrm{H}, 2 \mathrm{NH}$ ); ${ }^{13} \mathrm{C}$ NMR (DMSO- $\left.d_{6}, 100 \mathrm{MHz}\right) \delta: 19.9,42.8$, 43.5, 55.1, 56.7, 122.6, 123.7, 125.6, 128.4, 130.7, 131.4, 135.2, 136.5, 138.3, 142.1, 167.6, $169.9 \mathrm{~cm}^{-1}$; FT-IR (KBr) v: $3448(\mathrm{NH}), 1705(\mathrm{C}=\mathrm{O}), 1662(\mathrm{C}=\mathrm{O}), 1518(\mathrm{C}=\mathrm{C})$, 1246 (C-O) $\mathrm{cm}^{-1}$; MS (EI) (m/z): $381\left(\mathrm{M}^{+}\right)$; Anal. Calcd. for $\mathrm{C}_{21} \mathrm{H}_{23} \mathrm{~N}_{3} \mathrm{O}_{4}(\mathrm{Mr}=381.17)$ : $\mathrm{C} 66.13, \mathrm{H} 6.08, \mathrm{~N} 11.02$. Found C 66.24, H 5.99, N 10.93.

\section{4. Catalyst Recovery}

In order to investigate of reusability of the nanocatalyst, the reaction of $o$-phenylenediamine, Meldrum's and tert-buthyl isocyanide (model reaction) were carried out several times using recovered copper iodide nanoparticles.

Briefly, after completion of the process, the CuI nanoparticles were separated by filtration and then were washed three to four times with methanol and ethyl acetate and dried in an oven overnight at $70{ }^{\circ} \mathrm{C}$. The separated catalyst was used five times in the model study with a slightly decreased activity as shown in Table 4 . It seems that the reusability of the catalyst in the synthesis of ben$\mathrm{zo}[\mathrm{b}][1,5]$ diazepin $\mathbf{4 b}$ is similar to the reaction of other substrates.
Table 4. Reusability of the copper iodide nanoparticles

\begin{tabular}{lcccc}
\hline First & Second & $\begin{array}{c}\text { Yield (\%) } \\
\text { Third }\end{array}$ & Fourth & Fifth \\
\hline 97 & 95 & 94 & 90 & 88 \\
\hline
\end{tabular}

\section{Conclusions}

In summary, we have successfully demonstrated unique catalytic activity of copper iodide nanoparticles in the synthesis of benzo[b][1,5]diazepine derivatives via three-component (Pseudo five-component) reaction of aromatic diamines, Meldrum's acid and isocyanides. The present approach is mild, easy, efficient and eco-friendly and the products were obtained in excellent yields and short reaction times. Also $\mathrm{CuI}$ nanoparticles with high surface area have significant advantages such as economical, recoverability, reusability and stability.

\section{Acknowledgements}

The author gratefully acknowledges the financial support of this work by the Research Affairs Office of the Islamic Azad University, Qom Branch, Qom, I. R. Iran.

\section{References}

1. J. K. Landquist, in: A. R. Katritzky, C. W. Pergamon (Ed.): In Comprehensive Heterocyclic Chemistry, Oxford, 1984; Vol. 1, pp. 166-170.

2. R. I. Fryer, Bicyclic Diazepines. In: Taylor EC (ed), Comprehensive Heterocyclic Chemistry, Wiley, New York, 1991; Vol. 50, Chapter. 22

3. V. H. Schütz, Benzodiazepines, Springer-Verlag: Berlin-Heidelberg, 1982.

http://dx.doi.org/10.1007/978-3-642-68426-5

4. R. K. Smalley, in: D. Barton (Ed): In Comprehensive Organic Chemistry, Pergamon: Oxford, 1979; Vol. 4.

5. K. S. Atwal, J. L. Bergey, A. Hedberg, S. Moreland, J. Med. Chem. 1987, 30, 635-640.

http://dx.doi.org/10.1021/jm00387a009

6. M. Di Braccio, G. Grossi, G. Roma, L. Vargiu, M. Mura, M. E. Marongiu, Eur. J. Med. Chem. 2001, 36, 935-949. http://dx.doi.org/10.1016/S0223-5234(01)01283-1

7. K. A. Parker, C. A. Coburn, J. Org. Chem. 1992, 57, 97-100. http://dx.doi.org/10.1021/jo00027a019

8. D. A. Claremon, N. Liverton, G. R. Smith, H. G. Selnick, U.S. Patent 5, 726, 171, 1998.

9. A. Leyva-Peìrez, J. R. Cabrero-Antonino, A. Corma, Tetrahedron 2010, 66, 8203-8209.

10. H. Kruse, Drug. Dev. Res. 1982, 2, 145-151. http://dx.doi.org/10.1002/ddr.430010719

11. M. E. Tranquillini, P. G. Cassara, M. Corsi G. Curotto, D. 
Donati, G. Finizia, G. Pentassuglia, S. Polinelli, G. Tarzia, A. Ursini, F. T. M. Van Amsterdam, Arch. Pharm. (Weinhein, Ger.) 1997, 330, 353-357.

12. B. M. Reddy, P. M. Sreekanth, Tetrahedron Lett. 2003, 44, 4447-4449. http://dx.doi.org/10.1016/S0040-4039(03)01034-7

13. S. R. Sarda, W. N. Jadhav, N. B. Kolhe, M. G. Landge, R. P. Paward, J. Iran. Chem. Soc. 2009, 6, 477-482.

14. J. Qian, Y. Liu, J. Cui, Z. Xu, J. Org. Chem. 2012, 77, 44844490. http://dx.doi.org/10.1021/jo300543n

15. J. S. Yadav, B. V. S. Reddy, G. Satheesh, G. Srinivasulu, A. C. Kunwar, Arkivoc 2005, (iii), 221-227. http://dx.doi.org/10.3998/ark.5550190.0006.324

16. R. Kaoua, N. Bennamane, S. Bakhta, S. Benadji, C. Rabia, B. Nedjar-Kolli, Molecules 2011, 16, 92-99. http://dx.doi.org/10.3390/molecules 16010092

17. G. Evano, N. Blanchard, M. Toumi, Chem. Rev. 2008, 108, 3054-3131. http://dx.doi.org/10.1021/cr8002505

18. M. Syamala, Org. Prep. Proced. Int. 2009, 41, 1-68. http://dx.doi.org/10.1080/00304940802711218

19. B. Morak-Miodawska, K. Pluta, Heterocycles 2009, 78, 1289-1298. http://dx.doi.org/10.3987/COM-08-11622

20. E. Moreno-Manas, R. Pleixats, Acc. Chem. Res. 2003, 36, 638-643. http://dx.doi.org/10.1021/ar020267y

21. L. Lu, M. L. Sui, K. Lu, Science 2000, 287, 1463-1465. http://dx.doi.org/10.1126/science.287.5457.1463

22. L. Rout, S. Jammi, T. Punniyamurthy, Org. Lett. 2007, 9, 3397-3399. http://dx.doi.org/10.1021/ol0713887

23. J. Suribabu, S. Sekarpandi, R. Laxmidhar, M. Tathagata, M. Santu, M. Raja, S. Prasenjit, T. Punniyamurthy, J. Org. Chem. 2009, 7, 1971-1976.

24. H-J. Xu, Y-F. Liang, Z-Y. Cai, H-X. Qi, C-Y. Yang, Y-S. Feng, J. Org. Chem. 2011, 76, 2296-2300.

http://dx.doi.org/10.1021/jo102506x
25. J. Safaei-Ghomi, S. Rohani, A. Ziarati, J. Nanostructures. 2012, 2, 97-83.

26. Y. Song, C. Yoo, J. T. Hong, S. J. Kim, H. A. Y. Jang, Bull. Korean Chem. Soc. 2008, 29, 1561-1564. http://dx.doi.org/10.5012/bkcs.2008.29.8.1561

27. M. Kidwai, N. K. Mishra, V. Bansal, A. Kuma, S. Mozumdar, Tetrahedron Lett. 2009, 5, 1355-1358. http://dx.doi.org/10.1016/j.tetlet.2009.01.031

28. A. K. Verma, R. Kumar, P. Chaudhary, A. Saxena, R. Shankar, S. Mozumdar, R. Chandra, Tetrahedron Lett. 2005, 46, 5229-5232. http://dx.doi.org/10.1016/j.tetlet.2005.05.108

29. A. K. Edward, L. M. Anton, S. K. Yulia, A. S. Vitaliy, V. Sergey, Appl. Catal. A: Gen. 2010, 385, 62-72. http://dx.doi.org/10.1016/j.apcata.2010.06.042

30. A. Shaabani, A. H. Rezayan, S. Keshipour, A. Sarvary, S. Weng, Org. Lett. 2009, 11, 3342-3245. http://dx.doi.org/10.1021/ol901196z

31. M. A. Ghasemzadeh, J. Safaei-Ghomi, H. Molaei, C. R. Chimie. 2012, 15, 969-974.

32. J. Safaei-Ghomi, M. A. Ghasemzadeh, Chin. Chem. Lett. 2012, 23, 1225-1229. http://dx.doi.org/10.1016/j.cclet.2012.09.016

33. J. Safaei-Ghomi, M. A. Ghasemzadeh, J. Chem. Sci. 2013, 125, 1003-1008. http://dx.doi.org/10.1007/s12039-013-0451-5

34. J. Safaei-Ghomi, M. A. Ghasemzadeh, M. Mehrabi, Sci. Iran. Trans C. 2013, 20, 549-554.

35. J. Safaei-Ghomi, M. A. Ghasemzadeh, Acta. Chim. Slov. 2012, 59, 697-702.

36. M. A. Ghasemzadeh, J. Safaei-Ghomi, S. Zahedi, J. Serb. Chem. Soc. 2013, 78, 769-779.

37. M. A. Ghasemzadeh, J. Safaei-Ghomi, J. Chem. Res. 2014, 5, 313-316. http://dx.doi.org/10.3184/174751914X13976454726953

38. Y. Yang, S. Liu, K. Kimura, Chem. Lett. 2005, 34, 1158- 1159. http://dx.doi.org/10.1246/cl.2005.1158

\section{Povzetek}

$\mathrm{CuI}$ nanodelci učinkovito katalizirajo multikomponentno kondenzacijo Meldrumove kisline in izocianidov $\mathrm{v}$ benzo[b][1,5]diazepinske derivate. Ta metoda omogoča sintezo različnih farmacevtsko in biološko aktivnih benzo[b][1,5]diazepinov z odličnimi izkoristki in v kratkem reakcijskem času. Glavne prednosti nanodelcev bakrovega(I) jodida so: enostavna priprava, nizka cena, visoka stabilnost, uporaba v nizkih deležih in možnost ponovne uporabe katalizatorja. Sintetizirani CuI nanodelci so bili karakterizirani z XRD, EDX, FT-IR, SEM in TEM analizo. 